\title{
AHUS eller Ahus?
}

Forbokstavsord (også kalt initialord) er forkortelser basert på forbokstaver. Dersom de leses bokstav for bokstav, skal de skrives med store bokstaver, for eksempel INR (internasjonal normalisert ratio), CT og MR. Men hvis navnet kan leses som et vanlig ord, er det valgfritt å bruke store eller små bokstaver, for eksempel PEG (perkutan endoskopisk gastrostomi) (1). Forkortelsen for Akershus universitetssykehus kan dermed både skrives som AHUS og Ahus.

Forkortelsene Ahus og AHUS blir brukt om hverandre både av helsepersonell, i mediene og i regjeringsdokumenter (2). Helseforetaket ønsker imidlertid at Ahus skal brukes, og det samsvarer også med anbefalingene fra Språkrådet (1).

\section{Kashif Waqar Faiz}

kashif.faiz@medisin.uio.no

Kashif Waqar Faiz (f. 1978) er spesialist i nevrologi, ph.d. og seksjonsleder/overlege og forsker ved henholdsvis Nevroklinikken og Avdeling for helsetjenesteforskning $(\mathrm{H} \emptyset \mathrm{KH})$, Akershus universitetssykehus.

Litteratur

1. Forkortelser. Språkrådet. www.sprakradet.no/ sprakhjelp/Skriveregler/Forkortinger/ (10.8.2016).

2. Meld. St. 11 (2015-2016). Nasjonal helse- og sykehusplan (2016-2019): 95, 104, 113 www.regjeringen.no/no/dokumenter/meld.-st.-1120152016/id2462047/ (1.11.2016)

\section{MERS eller mers?}

Mers - Middle East respiratory syndrome - er en alvorlig influensalignende sykdom som ble oppdaget i 2012. På norsk er skrivemåten mers, altså med små bokstaver.

Sykdommen har fått navn fra Midtøsten, siden det var der de første tilfellene dukket opp. På norsk kan det hete «midtøstluftveissyndrom» $(1,2)$, men det er langt og tungvint og kommer nok i praksis til å bli lite brukt.

Mers skyldes et tidligere ukjent coronavirus $(1,2)$. Sykdommen har mye til felles med sars (severe acute respiratory syndrome), som ble oppdaget i Kina i 2002 (3). Mersviruset ble første gang isolert fra en pasient som døde i 2012 i Saudi-Arabia. Tilfellet ble publisert i detalj samme år (4).

Over 1800 laboratoriebekreftede tilfeller fra 27 land er hittil rapportert til WHO, med dødelig utgang hos $35 \%$ (5). Det er fortsatt mange ubesvarte spørsmål om epidemiologi, patogenese, spredning og behandling (6).

\section{På norsk}

Verdens helseorganisasjon kalte opprinnelig det nye viruset for «the novel coronavirus» (7). I 2012 foreslo nederlandske forskere at det burde hete Human Coronavirus-Erasmus Medical Center (HCoV-EMC) (4). I mai 2013 anbefalte imidlertid en internasjonal komité navnet Middle East Respiratory Syndrome Coronavirus (MERS-CoV). Det ble også sterkt anbefalt av WHO, det ville «provide uniformity and facilitate communication about the disease» (8). Forkortelsen er altså MERS-CoV, der CoV står for coronavirus. Men til daglig bruk blir dette for langt - mers er kort og greit.

Forkortelser for sykdomsnavn blir ofte skrevet med store bokstaver når de er helt nye, men etter hvert som de slår rot i språket, blir de oppfattet som vanlige ord og skrevet med små bokstaver (9). Språkrådet tilrår skrivemåten mers, på linje med bl.a. sars, aids, hiv og kols (10).

Både forkjølelse, sars og mers har opphav i den store virusfamilien som kalles coronavirusene (av latin corona «krans, ring»). På Språkrådets sider skrives coronavirus med $\mathrm{k}$ (10), men her vil Tidsskriftet følge en annen praksis. I Tidsskriftet bruker vi den klassiske skrivemåten når grunnordet er del av et sammensatt ord, som forledd eller etterledd, f.eks. thoraxkirurgi, oesophagusokklusjon eller hydrocephalus (11). Derfor vil vi også skrive coronavirus med c (12).

\section{Erlend Hem}

erlend.hem@medisin.uio.no

Erlend Hem (f. 1970) er dr.med., fagsjef i Klinikk psykisk helse og avhengighet, Oslo universitetssykehus, og redaktør for Tidsskriftets språkspalte.

\section{Litteratur}

Brodwall K. Nytt alvorlig luftveissyndrom. Tidsskr Nor Legeforen 2013; 133: 2043

2. Brodwall K. Midtøstluftveissyndrom. Tidsskr Nor Legeforen 2015; 135: 1444

3. Aavitsland P. Influensa eller SARS? Tidsskr Nor Lægeforen 2003; 123: 3175.

4. Zaki AM, van Boheemen S, Bestebroer TM et al. Isolation of a novel coronavirus from a man with pneumonia in Saudi Arabia. N Engl J Med 2012; 367: 1814-20.

5. Middle East respiratory syndrome coronavirus (MERS-CoV). World Health Organization. www who.int/emergencies/mers-cov/en/ (10.10.2016).

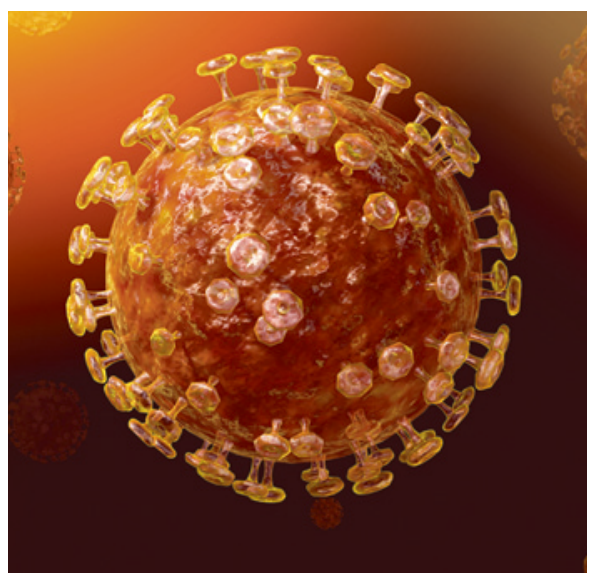

Mersvirus. Illustrasjon: Thinkstock

6. Zumla A, Hui DS, Perlman S. Middle East respiratory syndrome. Lancet 2015; 386: 995-1007

7. Novel coronavirus infection - update. World Health Organization 23.11.2012. www.who.int/csr/don/ 201211 23/en/ (10.10.2016).

8. Novel coronavirus update - new virus to be called MERS-CoV. World Health Organization 16.5.2013. www.euro.who.int/en/health-topics/emergencies/ international-health-regulations/news/news/ 2013/05/novel-coronavirus-update-new-virus-tobe-called-mers-cov (10.10.2016)

9. Språkleg førstehjelp. Språkrådet. http://www.sprakradet.no/Vi-og-vart/Publikasjoner/ Statssprak/statssprak-22016/sprakleg-forstehjelp/ (10.10.2016).

10. Mers/MERS. Aktuelt ord. Språkrådet 12.6.2015. www.sprakradet.no/Vi-og-vart/hva-skjer/Aktueltord/mersmers (10.10.2016).

11. Latinske og greske ord og uttrykk. Forfatterveiledningen. Tidsskrift for Den norske legeforening. http://tidsskriftet.no/annet/latinske-og-greskeord-og-uttrykk (10.10.2016).

12. Tønjum T, Myrvang B. (8.3.2016). Mers. I: Store medisinske leksikon. https://sml.snl.no/MERS (10.10.2016). 